\title{
Breaking Out of Carbon Lock-In: Malaysia's Path to Decarbonization
}

\author{
Lawrence Susskind*, Jungwoo Chun, Selmah Goldberg, Jessica A. Gordon, \\ Griffin Smith and Yasmin Zaerpoor
}

Department of Urban Studies and Planning, Massachusetts Institute of Technology, Cambridge, MA, United States

\section{OPEN ACCESS}

Edited by:

Marina Alberti,

University of Washington,

United States

Reviewed by:

Michinori Uwasu,

Osaka University, Japan

Bao-Jie He,

University of New South Wales,

Australia

*Correspondence: Lawrence Susskind

susskind@mit.edu

Specialty section:

This article was submitted to

Urban Science,

a section of the journal

Frontiers in Built Environment

Received: 27 March 2019

Accepted: 13 February 2020

Published: 27 March 2020

Citation:

Susskind L, Chun J, Goldberg S, Gordon JA, Smith G and Zaerpoor Y

(2020) Breaking Out of Carbon

Lock-In: Malaysia's Path

to Decarbonization.

Front. Built Environ. 6:21 doi: 10.3389/fbuil.2020.00021
Malaysia has made an ambitious commitment to reduce the intensity of its carbon emissions, notably a 40\% reduction (compared to 2005 levels) by 2020 and a 45\% reduction (compared to 2005 levels) by 2030. As with other developing countries, Malaysia's challenge is to decarbonize its energy-centric economy in the face of population growth pressures and substantial levels of poverty. Drawing on extensive interviews with both public and private stakeholders, we examine how Malaysia has launched its transition to a decarbonized development path. Based on our multiyear analysis, we identify key breakout factors, including behavioral transformations, institutional shifts, and action by a broad network of actors that have allowed Malaysia to begin decarbonizing its economy. At the same time, we note that federal-state friction, limited government capacity, the absence of a centralized management agency, the lack of international funding, incipient environmental awareness, and numerous barriers to investment in renewable energy reinforce carbon lock-in. Our analysis suggests ways in which other rapidly developing countries can learn from Malaysia's initial successes and challenges.

Keywords: decarbonization, Malaysia, carbon emission, lock-in, climate change, renewable and sustainable energy

\section{INTRODUCTION}

The Paris Agreement, ratified by 175 countries, calls for limiting global mean temperature rise to below $2^{\circ} \mathrm{C}$, and, ideally, below $1.5^{\circ} \mathrm{C}$ (UNFCCC, 2015). To meet the $2^{\circ}$ goal, the Intergovernmental Panel on Climate Change (IPCC) argues that global annual Greenhouse Gas (GHG) emissions must be reduced $42-57 \%$ by 2050 (relative to 2010 levels) and $73-107 \%$ by 2100 (IPCC, 2015). This monumental task will require extensive decarbonization of economic growth.

Malaysia promised to participate in global efforts to address climate change even before the Paris Agreement was signed. In 2009, at the United Nations Framework Convention on Climate Change (UNFCCC) meeting in Copenhagen, former Malaysian Prime Minister Najib Razak announced that Malaysia would pursue a $40 \%$ reduction in its carbon emission intensity (compared to 2005 levels) by 2020, contingent on adequate technology transfer and financing from the developed world. Although the additional financing and technology were not forthcoming, Malaysia was able to achieve a carbon emissions intensity reduction of 33\% by 2011 and is likely to meet its goal (Ministry of Natural Resources and Environment, 2015; Razak, 2016). Malaysia's latest commitment, reflected in its Nationally Determined Contribution (NDC) to the Paris Agreement, is to reduce its emissions intensity by $45 \%$ by 2030 (relative to its emissions intensity 
per unit of GDP in 2005), with $10 \%$ of this goal contingent upon international assistance.

This is a very ambitious commitment given that fossil fuel is a key driver of Malaysia's economy. It currently has the second highest demand for energy per capita in the region (Gouldson et al., 2014). Malaysia, and other rapidly developing countries, face the difficult challenge of decarbonizing their economies while their population increases and they need to grow their GDPs so they can alleviate substantial levels of poverty (IPCC, 2015; Roser and Ortiz-Ospina, 2017). Much of the success of global decarbonization efforts will depend on the ability of Malaysia and other developing countries to transition to a "low carbon development path." In light of this, we ask: How has Malaysia launched its transition to a sustainable, decarbonized development path? What successes has Malaysia had thus far, and what are the barriers to further decarbonization across key sectors of the country? What can other rapidly industrializing countries learn from Malaysia's efforts?

We find that federal-state friction, limited government capacity, the absence of a centralized management agency, the lack of international funding, incipient environmental awareness, and numerous barriers to investment in renewable energy (RE) constrain decarbonization and reinforce carbon lock-in in Malaysia. Conversely, several breakout factors (categorized in this paper and related literature as behavioral transformations, institutional shifts, and action by broad networks of actors) have allowed Malaysia to escape path-dependent carbon lock-in and move in a new decarbonization direction.

The next section of this paper reviews Malaysia's current decarbonization plan along with public perceptions of the actions that have been proposed. We will then detail Malaysia's sectoral decarbonization efforts and analyze their success thus far as well as the challenges they still face. We will conclude with policy recommendations to Malaysia's new government.

\section{MALAYSIA'S LOW CARBON DEVELOPMENT PATHWAY}

Malaysia's commitment to reducing carbon emissions started in 2006, 3 years prior to Prime Minister Razak's public statement. Since then, a number of policies and strategic plans ${ }^{1}$ have slowly redirected the country toward a less carbon-intensive future. These have included adding palm biodiesel to diesel fuel (National Biofuel Industry Act, 2007); establishment of a Sustainable Energy Development Authority (SEDA) to promote the use of renewable energy in power generation; promotion of public transportation while limiting private vehicle ownership (National Land Public Transport Master Plan); and encouraging adoption of "green" technology (KeTTHA, 2017b).

\footnotetext{
${ }^{1}$ The plans that describe Malaysia's carbon intensity reduction actions include the Ninth Malaysia Plan (2006-2010), the Tenth Malaysia Plan (2011-2015), the National Land Public Transport Master Plan (2012-2030), the Eleventh Malaysia Plan (2016-2020) and the Green Technology Master Plan (2017). The main supporting policies include the National Biofuel Industry Act (2007), and the National Renewable Energy Policy (2010)
}

The last of these, the Green Technology Master Plan (20172030), outlines multi-sectoral efforts to reduce greenhouse gas (GHG) emission intensity by $45 \%$ by 2030 and support economic growth through green technology adoption. In the transport sector, Malaysia aims to reach $40 \%$ overall public transport modal share by 2030, almost doubling the current modal share of about 20\% (KeTTHA, 2017a,b). The Master Plan also set an ambitious target of $100 \%$ of all newly registered cars to be either hybrid or electric vehicles (KeTTHA, 2017a). Other plans include promoting the growth of compressed natural gas (CNG) sales coupled with higher fuel standards for vehicles, implementing green building certification schemes, and improving waste management methods (KeTTHA, 2017a). For an overview of Malaysia's sector-specific carbon emission intensity reduction strategies, see Appendix A.

Malaysia calculates the intensity of its carbon emissions with and without the inclusion of land use and forestry (LULUCF) sector emissions and on both a per capita and per unit of GDP basis. Excluding LULUCF removals, the government reported $2011 \mathrm{GHG}$ emissions at 9.97 tons $\mathrm{CO}_{2}$ equivalent per capita and 0.41 tons $\mathrm{CO}_{2}$ equivalent per thousand ringgit (9.8 and 23.0\% intensity reductions from 2005 levels, respectively. With the inclusion of LULUCF removals (socalled "carbon sinks"), 2011 GHG emissions were 0.94 tons $\mathrm{CO}_{2}$ eq per capita and 0.04 tons $\mathrm{CO}_{2}$ eq per thousand Ringgit (20.7 and 32.5\% intensity reductions from 2005 levels) (Ministry of Natural Resources and Environment, 2015).

Malaysia's reported carbon emissions intensity reduction of $32.5 \%$ in 2011 equals a reduction of $18,578.80 \mathrm{ktCO}_{2} \mathrm{eq}(2013$ data). Malaysia is pursuing several approaches in different sectors to achieve these reductions. Figure 1, which illustrates the percent emission reduction achieved through various mitigation tools in 2013 (Ministry of Natural Resources and Environment, 2015), shows that forest gazetting (i.e., permanently listing forested areas as conservation areas) accounts for the vast majority (almost 75\%) of the reported reductions. Gazetting a forest is achieved merely by shifting existing forest area (on a map) from production to conservation use. While gazetting represents a laudable policy objective (i.e., maintaining significant carbon sink capacity), it does not represent a real reduction of carbon emissions compared to prior years. Thus, Malaysia's other mitigation policies, while less significant in terms of reducing carbon intensity on paper, are important in terms of reducing actual emission levels.

Moreover, it is important to emphasize that Malaysia's 45\% carbon intensity reduction target is per unit of GDP. Using this measure, rather than a measure of absolute reduction, means that as Malaysia's GDP increases, the country's total GHG emissions can increase along with it. Therefore, Malaysia could reach its intensity target while total GHG emissions may increase (in fact, this will almost certainly be the case) (Zhu et al., 2014; UNFCCC, 2018a). Measuring emissions per unit of GDP reflects the challenge that many countries face of doing their fair share to reduce global GHG emissions while also encouraging rapid economic growth. Malaysia currently states that its overall objective is to achieve "green growth" while sustaining socio-economic development (11th Malaysia Plan). 


\section{Percent of Total Reduction of Mitigation Policies}

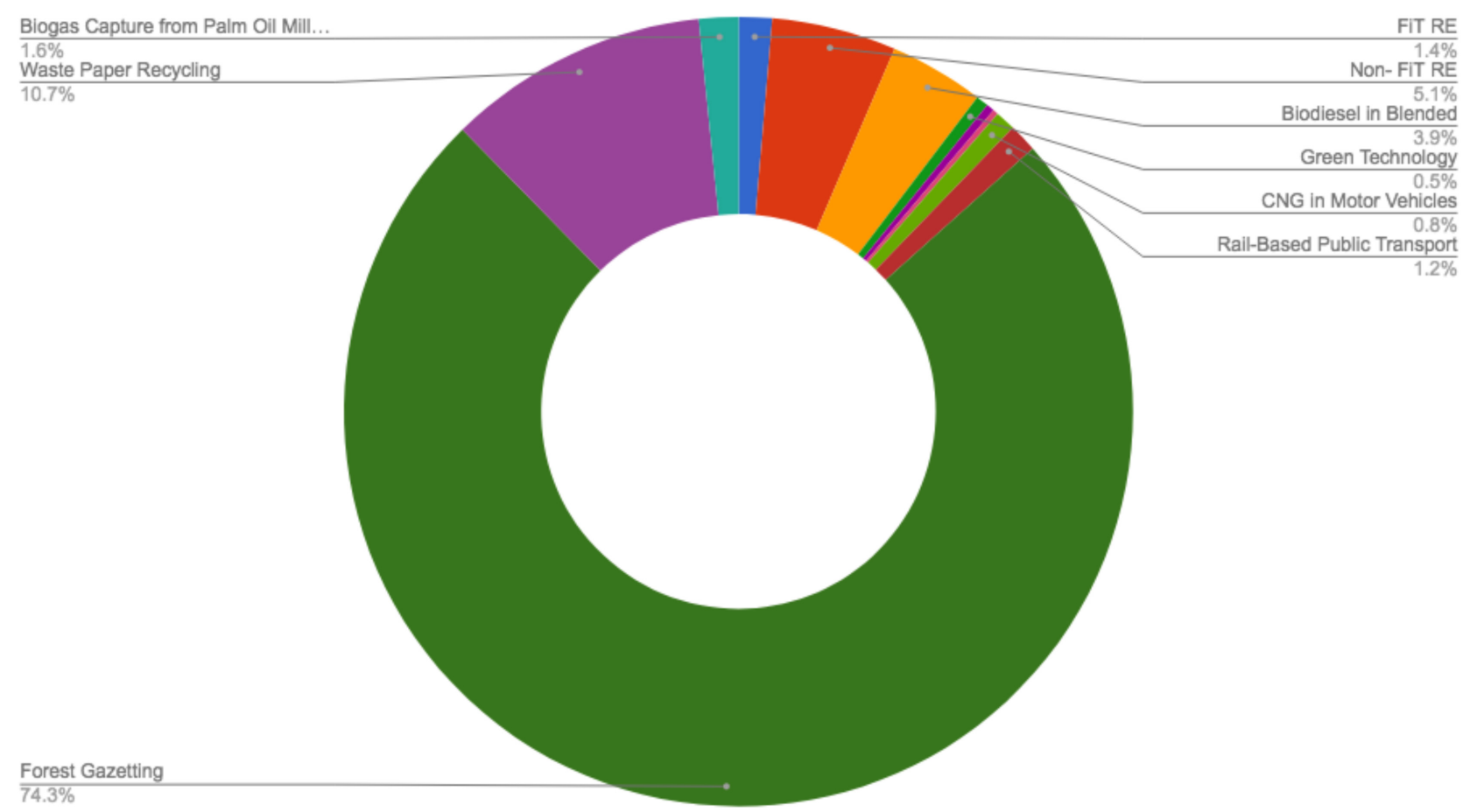

FIGURE 1 | Percentage of Emission Reduction by Mitigation Tools (2013). Data from the first Malaysian Biennial Update Report (Ministry of Natural Resources and Environment, 2015).

Focusing on emissions intensity per unit of GDP will allow them to do this.

\section{DATA COLLECTION AND ANALYSIS}

While numerous government reports outline specific sources of GHG emissions in Malaysia in quantitative terms, we were more interested in the bigger picture. Our goal is to understand the central drivers of decarbonization efforts over the past 10 years as well as the challenges, successes, and lessons that might be relevant to other developing countries.

\section{Data Collection}

Between December 2017 and January 2018, we conducted twenty-two interviews with fifty-six individuals (Table 1). Our goal was to interview a representative cross-section of all major stakeholders relevant to Malaysia's economic, political and societal transition to a lower-carbon future. This included federal, state and local government representatives, large corporations, international organizations, local NGOs and civil society organizations, and academia. As we identified potential interviewees across these sectors, we aimed to include industries that have been recognized as the greatest contributors to GHG emissions in Malaysia, including energy, waste, heavy industry, agriculture, LULUCF, and transport (Ministry of Natural Resources and Environment, 2015). Of approximately fifty agencies, companies and organizations we contacted, about half agreed to an interview. Despite our attempts to arrange interviews with representatives of all major stakeholder categories, lack of response to some interview requests resulted in gaps in input from certain industries, though we improved representativeness through using a snowball approach when conducting interviews. Interviewees were mostly Malaysian stakeholders, although we also spoke with staff at international development agencies. Our interviewees included: three government agencies that deal primarily with energy and environmental issues; six companies representing the energy, forestry, and finance industries; five environmental non-governmental organizations; representatives from three international development organizations; four academics; and one member of Malaysia's major opposition political party.

TABLE 1 | Overview of individuals contacted and interviewed by sector.

\begin{tabular}{lccc}
\hline Sector & $\begin{array}{c}\text { No. individuals } \\
\text { contacted }\end{array}$ & $\begin{array}{c}\text { No. individuals } \\
\text { responded }\end{array}$ & No. interviews \\
\hline Government & 19 & 6 & 4 \\
Private & 8 & 3 & 5 \\
NGO & 16 & 11 & 8 \\
Academia & 8 & 6 & 4 \\
Total & 51 & 26 & 22
\end{tabular}


Interviews were semi-structured, that is, all included certain common questions, but most also included questions unique to the work of each interviewee. A compilation of common questions across all interviews can be found in Appendix B. Interviews ranged in length from one to two and a half hours, for an average of about $75 \mathrm{~min}$. Although we identified and targeted additional industries integral to Malaysia's carbon mitigation efforts (such as construction and waste management), we were not able to secure interviews in these areas.

\section{Data Analysis}

Written notes were taken during every interview. When given permission, interviews were audio recorded and transcribed. Interview data were coded using a multi-step, iterative process following Corbin and Strauss (2008). First, we gathered all available data on climate mitigation. Four researchers were involved to reduce the risk of bypassing significant data sources. Then, we distilled all this information into six analytical categories: carbon mitigation successes, carbon mitigation barriers, comments on Malaysia's efforts to reach its carbon emissions reduction targets, recommendations regarding possible ways forward, and common themes across actors and sectors. Next, the information from each interview was coded according to these categories. Our final coding process involved grouping these analytical categories into several cross-cutting themes. Examples of these themes include conflicting identity, federalism challenges, financing needs, public awareness on the need to address climate change, and renewable energy use. Sorting the data into categories and re-analyzing the cross-cutting themes made clear where Malaysia has made progress in transitioning to a low-carbon society and the policy tools it has used to do so. The process of analysis also allowed us to identify the obstacles likely to make it difficult for Malaysia to meet its future emission reduction targets.

\section{MALAYSIA'S LOW-CARBON POLICY TOOLKIT}

Based on our interviews, we identified policy approaches that fit within what we call a low-carbon policy toolkit (Table 2). The tools listed contribute in different ways to carbon emission intensity reduction. We also note which tools might be generalizable to other contexts, and which were given priority by our interviewees.

For each of the three main policy approaches (strengthen forest management and conservation, increase renewable energy use, and improve urban planning and promote public transportation) we discuss the tools used in Malaysia to implement the selected policy approach, the success of these tools and the remaining challenges.

\section{Strengthen Forest Management and Conservation}

Malaysia has extensive forests in both the Peninsula part of the country and in East Malaysia, with the majority of forest (86\%) in Sarawak and Sabah (the two states of East Malaysia) (World
TABLE 2 | Malaysia's low-carbon policy toolkit ${ }^{1}$.

\begin{tabular}{|c|c|}
\hline Policy approach & Low-carbon policy tools \\
\hline $\begin{array}{l}\text { Strengthen Forest } \\
\text { Management and } \\
\text { Conservation }\end{array}$ & $\begin{array}{l}\text { (i) Increased Gazetting; (ii) Establishment of Conservation } \\
\text { Trust Fund; (iii) Implementation of REDD }+^{2}\end{array}$ \\
\hline $\begin{array}{l}\text { Increase } \\
\text { Renewable Energy } \\
\text { Use }\end{array}$ & $\begin{array}{l}\text { (i) Establishment of Feed in Tariff*; (ii) Introduction of Net } \\
\text { metering*; (iii) Creation of Green Technology Financing } \text { Scheme }^{\star} \text {; (iv) Increased RE electricity generation by } \\
\text { non-Feed-in Tariff; regulated public and private licensees } \\
\text { and other mechanisms; (v) Introduction of B10 biodiesel }{ }^{3} \text {; } \\
\text { and (vi) Launch of green sukuk investment instrument }{ }^{4}\end{array}$ \\
\hline $\begin{array}{l}\text { Improve Urban } \\
\text { Planning and } \\
\text { Promote Public } \\
\text { Transportation }\end{array}$ & $\begin{array}{l}\text { (i) Improved integration of urban nodes and planning (and } \\
\text { related plans)*; (ii) Development of rail-based public } \\
\text { transport; and (iii) Removal of fossil fuel subsidies }\end{array}$ \\
\hline
\end{tabular}

${ }^{1}$ Interventions that were most often referred to in interviews are denoted by an asterisk and are discussed at greater length in text. ${ }^{2}$ REDD + refers to the United Nations Reducing Emissions from Deforestation and Forest Degradation Program initiated in 2008 (UNFCCC, 2018b). ${ }^{3}$ B10 biodiesel is fuel comprised of $10 \%$ palm methyl ester. ${ }^{4}$ The green sukuk, first of its kind and launched in June 2017 , is an Islamic bond in which returns are used to invest in environmentally sustainable infrastructure projects.

Resources Institute and Global Forest Watch, 2018). Statistics from the Malaysian government and NGOs differ with regard to the exact amount of forested land that exists. The total stands somewhere between 16.8 and 19.3 million hectares (Ministry of Natural Resources and Environment, 2015; World Resources Institute and Global Forest Watch, 2018). These vast areas of forest provide natural carbon sinks, offsetting approximately 90\% of Malaysia's annual GHG emissions (Ministry of Natural Resources and Environment, 2015). However, deforestation driven primarily by expansion of areas for palm oil production, human development, and new infrastructure - and degradation driven primarily by logging - threaten the future of Malaysia's forests. Malaysia has lost $23.1 \%$ of its tree cover since 2000. This is equal to $732 \mathrm{Mt}$ of $\mathrm{CO}_{2}$ emissions (World Resources Institute and Global Forest Watch, 2018).

Malaysia has responded to deforestation by encouraging permanent gazetting of forests to encourage their long-term protection (Ministry of Natural Resources and Environment, 2015; Confidential, 2018b, I. 3; Gitano-Briggs et al., 2018, I. 6; Confidential, 2017/2018, I. 10; Jinggut and Dzulkifli, 2018). Several Malaysian state governments, which control forests, have increased their rates of gazetting state forests in the last 5 years and reduced incidences of illegal logging. Sabah and Sarawak have powerful and environmentally oriented forestry ministries and have led the way in forest protection. Sabah's Forestry Department has proven particularly effective, passing more stringent protection goals and requiring palm oil certification. ${ }^{2}$ NGOs have worked closely with Sabah's government to conserve forest resources.

Private industry has supported forest conservation efforts. Sime Darby, the largest palm oil producer in Malaysia, has a

${ }^{2}$ Palm oil producers can voluntarily choose to meet environmental and social criteria and receive third party certification. For example, the Roundtable on Sustainable Palm Oil (RSPO) certifies producers who meet criteria that minimize the negative environmental and social impacts of palm production. 
"no deforestation" policy and has not developed any greenfields since 2005 or peatland since 2010. Malaysia's increased exposure to global markets has made corporations more responsive to international consumers who increasingly demand proof of sustainable practices before they will buy products (Confidential, 2017/2018, I. 10, Confidential, 2018g, I. 16).

Domestic environmentalism is also on the rise in Malaysia, particularly with a focus on preserving biodiversity. NGOs and the federal government have taken advantage of this growing attention to highlight the importance of forest protection. In addition, Malaysians are starting to capitalize on the economic benefits of intact forests, operating a growing number of ecotourism operations for domestic and international visitors (Confidential, 2017/2018, I. 10, Confidential, 2018d, I. 21, Confidential, 2018i, I. 23; Jinggut and Dzulkifli, 2018, I. 18; Navaratnam and Confidential, 2018).

Interviewees explained the numerous challenges that impede efforts to gazet forests. First, there is disagreement over the extent of illegal logging and clearing of forests for farms. Most interviewees noted this as a minor problem. Several highlighted legal logging, Eastern Malaysia's largest industry, as more problematic; timber companies frequently harvest more than their allotted shares and expel local citizens within industry concession areas (Amir, 2018, I. 20; Confidential, 2018b, I. 3, Confidential, 2017/2018, I. 10; Gitano-Briggs et al., 2018; Jinggut and Dzulkifli, 2018, I. 18; Rao, 2018, I. 8; Wong, 2018). Second, interviewees underscored the difficulty of gazetting compared to the ease of degazetting forests. Degazetting requires no public notice, making it difficult to mobilize against specific degazetting efforts (Jinggut and Dzulkifli, 2018). If protected forests can be easily degazetted, how effective is this decarbonization tool to be in the long term? Third, interviewees pointed to the inability of the federal and state governments to adequately enforce quotas, catch falsified documents, combat local corruption and sufficiently protect forests from illegal logging. Others lauded current efforts to gazette forests while commenting on the irreversible loss of many pristine areas as well as expanded agricultural activities on or adjacent to forests (Confidential, 2018b, I. 3; Confidential, 2017/2018, I. 10; Jinggut and Dzulkifli, 2018). Fifth, although the current forest cover is roughly 59\%, protection plans only outline a goal of preserving 50\% canopy cover. This means that the government "can just sit back and wait." Sixth, the government does not seem to be committed to ensuring that forests are not converted to other land uses. For example, although the government promised to limit total palm oil plantations to six million hectares, it has been silent on this topic since that limit was exceeded. Others point to the destruction of supposedly protected forests so that new infrastructure projects could be built (Confidential, 2018b, I. 3, Confidential, 2017/2018, I. 10; Gitano-Briggs et al., 2018; Jinggut and Dzulkifli, 2018; Wong, 2018). In addition, in most cases, forest areas are gazetted as permanent forest reserves (as opposed to national or state parks). This classification does not exclude logging. Logging done through Sustainable Forest Management (SFM) practices is still allowed. However, this type of logging is linked to increased forest degradation (Wong, 2018).
Ambiguity surrounding data sources and land type classifications poses challenges. There is widespread uncertainty, even among environmental NGOs, over what type of plantation land counts as forest. There are also discrepancies between government statistics about the amount of protected land and figures from non-governmental groups that suggest less land has been protected. Moreover, several people commented on the difficulty of accurately gaging true increases in forest canopy without evidence of actual physical change (Amir, 2018; Confidential, 2018b, I. 3, Confidential, 2017/2018, I. 10, Confidential, 2018i, I. 23; Gitano-Briggs et al., 2018; Jinggut and Dzulkifli, 2018; Rao, 2018, I. 8; Wong, 2018). Finally, the international community is unwilling to pay what Malaysia views as a realistic price to subsidize forest protection through REDD $+^{3}$ and other programs. Some estimates indicate that developed countries will have to increase the price they pay for carbon offsets by 10 -fold to actually halt deforestation (Confidential, 2017/2018, I. 10; Confidential, 2018d, I. 12).

\section{Increase Renewable Energy Use}

Malaysia currently produces $22.4 \%$ of its power from renewable sources and aims to hit 30\% by 2030 (KeTTHA, 2017a; Ujang, 2018). Much of this renewable generation is from hydropower projects. Multiple interviewees pointed to the Feed in Tariff (FiT), Net Energy Metering (NEM), and Green Technology Financing Scheme (GTFS) policies adopted in the last few years as key drivers that could propel substantial new investment in RE (Confidential, 2018c, I. 11; Confidential, 2018e, I. 14; Confidential, 2018f, I. 15; Confidential, 2018h, I. 17; Harris, 2017; Ming and Dashun, 2018, I. 13; Rao, 2018, I. 8; Ujang, 2018). The FiT, established through the Renewable Energy Act of 2011, supports RE projects up to $30 \mathrm{MW}$ by mandating that energy utilities purchase independently produced power at a "premium" price for a period of up to 21 years. A $1.6 \%$ tax levied on the electricity bills of consumers who use more than $300 \mathrm{kWh} / \mathrm{month}$ of electricity feeds the Renewable Energy Fund that supports such payments to RE producers. The FiT covers biomass, biogas, small hydro, and solar projects (it does not cover wind projects).

NEM is intended to complement and eventually replace the FiT for solar energy. NEM makes it possible for domestic, commercial, and industrial electricity consumers to install solar panels for internal electricity use and selling excess electricity to the grid at an agreed-upon tariff price. Grid sales are deducted from a consumer's subsequent electricity bill (Confidential, 2018f, I. 15; Confidential, 2018h, I. 17; SEDA, 2018).

GreenTech Malaysia, a corporation which sits within the Ministry of Energy, Green Technology and Water (KeTTHA), has managed the GTFS since its launch in 2009. Producers and users of green technology can apply for government certification. Approved applicants can receive loans from private banks, known as Participating Financial Institutions (PFIs). The government guarantees $60 \%$ of the total approved loan up to RM 100 million for producers of certified technology and RM

${ }^{3}$ REDD + are initiatives and processes supported by the United Nations Collaborative Program on Reducing Emissions from Deforestation and Forest Degradation in Developing Countries. 
10 million for users of certified technology. The government also bears $2 \%$ of the interest charged by the PFI (Green Tech and Malaysia, 2016; Confidential, 2018c).

Interviewees highlighted several successes in the RE realm. The GTFS and the solar FiT are well-managed, easy to use programs. Both have allocated the entirety of their funds, probably because of high use levels (Confidential, 2018c, I. 11; Confidential, 2018d, I. 12; Confidential, 2018f, I. 15; Confidential, 2018h, I. 17; Ming and Dashun, 2018). While the solar FiT fund has less available money for new projects, Malaysia has learned from the problems facing similar international programs and incorporated a "short-circuit mechanism" to ensure existing projects do not lose funding at the expense of new applicants (Confidential, 2018f, I. 15). Interviewees pointed to the 21-year contracts allowed under the FiT as key to encouraging renewable energy project development by providing stability and ensuring cost recovery (Confidential, 2018c, I. 11; Confidential, 2018d, I. 12; Ming and Dashun, 2018, I. 13; Confidential, 2018f, I. 15; Confidential, 2018h, I. 17; Ujang, 2018).

Interviewees also praised the Sustainable Energy Development Authority (SEDA) ${ }^{4}$ and its efforts to roll out the FiT. SEDA has succeeded in demonstrating the profit potential of RE and translating awareness into action. SEDA has also worked closely with banks under the GTFS to help them learn more about RE, bolstering their confidence in investing in new technologies (Confidential, 2018c, I. 11; Confidential, 2018f, I. 15; Ming and Dashun, 2018). Certain Malaysian states have utilized these programs to become national leaders in RE. Penang, for example, has invested in solar rooftop installation while Sabah has focused on biomass/biogas. (Other states have focused on sustainable energy efforts outside of SEDA's scope, such as Sarawak's construction of the Bakun Hydro project (Navaratnam and Confidential, 2018).

Despite these successes, there are still economic, physical, and socio-political barriers to relying more heavily on RE. The FiT has faced accusations of non-transparent allocation of quotas. While SEDA has taken steps to create an open balloting process, this new process only applies to projects less than $1 \mathrm{MW}$ (Ming and Dashun, 2018). In addition, less overall funding for the large scale solar FiT has resulted in lower payment rates for new producers of solar energy. This has decreased profits for solar projects and made the program less attractive, limiting uptake. Similarly, the NEM program has attracted fewer users than expected, primarily due to insufficient tariff payments, caps on sales back to the grid, and provisions restricting third party installation (Confidential, 2018e, I. 14; Confidential, 2018f, I. 15; Confidential, 2018h, I. 17; Ming and Dashun, 2018; Navaratnam and Confidential, 2018). Some interviewees commented that the programs could be adjusted to ensure that utilities are fairly compensated for accepting RE at higher prices than the current rate (Confidential, 2018h, I. 17). Others worry that Tenaga Nasional Berhad (TNB), the sole electrical provider in peninsular Malaysia, outcompetes smaller bidders in auctions

\footnotetext{
${ }^{4}$ SEDA, created through the 2011 Sustainable Energy Development Authority Act 2011, advocates for the uptake of RE and manages RE programs, primarily the FiT and NEM.
}

to develop RE projects. Since they are the sole provider of transmission infrastructure, they should be required to develop additional grid infrastructure rather than compete to produce RE. In certain circumstances (depending on guidelines defined by TNB's contracts), there are no incentives for TNB to connect the grid to new RE production sites, sometimes requiring producers to develop their own grids (Navaratnam and Confidential, 2018).

Economic challenges, driven primarily by the low cost of coal and wary investors, have also stifled the development of RE. Coal power, the source of $31.1 \%$ of Malaysia's energy mix, allows for maintenance of cheap baseload electricity cost (Ministry of Natural Resources and Environment, 2015; Navaratnam and Confidential, 2018). Reduced coal power dependency in other developed countries has further lowered coal prices, making it more difficult for renewable sources and natural gas to compete. Government fossil fuel subsidies, though decreasing, create an even more unlevel playing field (Gitano-Briggs et al., 2018, I. 6; Confidential, 2018e, I. 14; Confidential, 2018f, I. 15; Confidential, 2018h, I. 17; Navaratnam and Confidential, 2018; Rao, 2018, I. 8). Banks remain skeptical about the viability of renewable energy projects due to uncertainties about their cost effectiveness, profitability, scalability, and high development costs (Confidential, 2018c, I. 11; Confidential, 2018f, I. 15; Confidential, 2018h, I. 17; Ming and Dashun, 2018; Navaratnam and Confidential, 2018).

Malaysia faces physical barriers to increasing the scope of renewable energy. Cloud cover and heat reduce the efficiency of photovoltaics and limited unused (non-forested or developed) land drives up prices (Confidential, 2018d, I. 12; Confidential, 2018h, I. 17; Gitano-Briggs et al., 2018). The availability of palm biogas and biomass is limited by seasonal palm fruit production and the distance between rural supply and urban demand. More research is needed to successfully commercialize palm-based biofuels (Confidential, 2018h, I. 17; Harris, 2017; Gitano-Briggs et al., 2018, I. 9). Both wind and large-scale hydropower are scarce and limited primarily to East Malaysia, away from major population centers (Confidential, 2018c, I. 11; Confidential, 2018d, I. 12; Confidential, 2018f, I. 15; Confidential, 2018h, I. 17; Gitano-Briggs et al., 2018).

Political leaders have proven unwilling to levy the necessary taxes to fully fund RE programs. While the targets for RE under the National Renewable Energy Policy and Action Plan (NREPAP) specifically from the FiT were based on a maximum $2 \%$ tax on consumer electricity use, the current tax is only $1.6 \%$ (though this is deemed to be high by many consumers). Politicians were wary of raising the tax, especially prior to the May 2018 election (Confidential, 2018f, I. 15; Confidential, 2018h, I. 17; Navaratnam and Confidential, 2018). It is not clear what the new government will do regarding rates. The Pakatan Harapan coalition campaigned heavily on boosting flagging economic growth, pledged to reintroduce automobile fuel subsidies, and since its electoral victory, appears to have placed little emphasis on environmental issues (Hamid, 2008; Au, 2016; Leong, 2018; Ruxyn, 2018; Siew, 2018).

Polluting industries buoy Malaysia's goal of reaching high income developed status by 2020, and economic concerns take precedence over environmental priorities. Malaysia's energy 
policies prioritize affordability, reliability, and sustainability in that order (Confidential, 2018h, I. 17; Confidential, 2018e, I. 14; Ujang, 2018; Wong, 2018). Furthermore, public awareness about the benefits of renewable energy is still nascent. Many Malaysians, particularly older generations, worry that increased RE will increase their electricity rates, and are adverse to paying more (Confidential, 2018f, I. 15; Confidential, 2018h, I. 17; Gitano-Briggs et al., 2018; Navaratnam and Confidential, 2018; Ujang, 2018).

\section{Improve Urban Planning and Promote Public Transportation}

Malaysia's transportation sector is the country's second most GHG intensive sector after electric power generation. Road vehicles produce $85.2 \%$ of sector emissions. $59 \%$ of these emissions come from personal vehicles, a product of Malaysia's high car ownership rate (Gitano and Leong, 2016; Gitano-Briggs, 2017; Gitano-Briggs et al., 2018). Multiple interviewees focused on the need for improved urban design and additional railbased transport as keys to mitigating $\mathrm{CO}_{2}$ emissions from the transport sector (Gitano-Briggs, 2017; Confidential, 2018a,b, I. 2; Gitano-Briggs et al., 2018; Jinggut and Dzulkifli, 2018; Ming and Dashun, 2018; Rao, 2018). These policy tools could play an important part in the government's efforts to reduce GHG emissions. While limited data exist to model the effects of alternative urban designs on emissions, as of 2013, one estimate is that rail-based mitigation actions [such as expansion of Light Rail Transit (LRT) and implementation of the Mass Rapid Transit system in the Klang Valley] alone have reduced emissions by $215 \mathrm{ktCO}_{2}$ eq (Ministry of Natural Resources and Environment, 2015). By 2020, expansion and improvement of rail service could more than quadruple emission reductions to $978 \mathrm{ktCO}_{2} \mathrm{eq}$, accounting for more than $3 \%$ of actual national reductions (Ministry of Natural Resources and Environment, 2015).

The Klang Valley region has seen the most dramatic improvements in transport connectivity (through changes in urban planning) over the past decade. In addition to completion of a new bus rapid transit line in 2015 and a mass rapid transit line in 2017, the government has improved physical and electronic infrastructure to better connect the multiple forms of public transport that already exist. Projects include covered walkways, street over paths, and development of single payment systems for multiple transit modes. Improved public transit options around Kuala Lumpur (combined with worsening road vehicle congestion) have bolstered ridership (Gitano and Leong, 2016; Gitano-Briggs, 2017; Confidential, 2018a, I. 2; Gitano-Briggs et al., 2018; Ming and Dashun, 2018). The federal government has signed an agreement with Singapore to construct a high-speed rail connection between Kuala Lumpur and Singapore. The project has the potential to reduce vehicle (and air) traffic in Malaysia's major North-South corridor once it is completed in 2026 (Gitano-Briggs et al., 2018).

Despite improved urban planning and public transport around Kuala Lumpur, the rest of the country has lagged behind. There is frequently limited connectivity and last mile gaps among existing transit options all over the country. Multiple cities have rail stations outside the city center that are not served by the local bus system, making it difficult to travel without a car (Gitano and Leong, 2016; Confidential, 2018a, I. 2; Gitano-Briggs et al., 2018). Land reclamation projects are popular in Malaysia, in part due to the difficulty of improving existing transportation infrastructure. Reclamation projects are seen as an "opportunity to build a new system rather than fix old messy systems... it's easier to build from scratch" (Confidential, 2018a, I. 2). In addition, Malaysia’s domestic car companies, particularly Proton, and the state oil company, PETRONAS, have instilled a strong sense of national pride in car ownership, making it difficult to shift riders to public transport (Confidential, 2018a, I2; Ming and Dashun, 2018; Rao, 2018).

The proposed high-speed rail line has stoked substantial political and environmental controversy. Some environmental groups oppose the line since it will cut through two protected forest areas (Confidential, 2018b, I. 3). There is also uncertainty about whether social norms around rail travel can be adjusted to generate adequate ridership (Confidential, 2018a, I2; Ming and Dashun, 2018; Rao, 2018). Moreover, now that the 2018 election is over, the future of the rail project is uncertain (Gitano-Briggs et al., 2018).

\section{WHAT CAN OTHER RAPIDLY DEVELOPING COUNTRIES LEARN FROM MALAYSIA'S EXPERIENCE?}

Other countries are attempting to decarbonize by shifting their energy sources away from fossil fuels toward renewable energy. Energy is the dominant source of greenhouse gas emissions, accounting for about two thirds of global emissions. Thus, energy must be a key component to any decarbonization plan. In high and middle income countries, decarbonization focuses on shifting the means of power generation, redesigning electricity grids, improving energy efficiency, and reducing industry and transport emissions (Fankhauser and Jotzo, 2018). According to an assessment by the International Energy Agency, meeting the Paris Agreement's goal of limiting global temperature rise to $2^{\circ}$ by 2050 will require an ambitious set of policy measures, including the rapid phase out of fossil fuel subsidies, a rise in $\mathrm{CO}_{2}$ prices to unprecedented levels, extensive energy market reforms, and stringent low-carbon and energy efficiency mandates (OECD/IEA and IRENA, 2017). More specifically, it will require nearly $95 \%$ of global electricity to come from lowcarbon sources, $70 \%$ of new cars to be electric, the entire building stock to be retrofitted, and $\mathrm{CO}_{2}$ intensity of the industrial sector to be $80 \%$ lower than it is today (OECD/IEA and IRENA, 2017). Such dramatic shifts demand not only adoption of new technologies, but also significant institutional, financial, and behavioral changes.

In the case of Malaysia, stakeholders pointed to several constraints to transitioning to a low-carbon society. We have consolidated these into six "categories" of constraints: federalstate friction; limited government capacity and willingness to regulate; absence of a dedicated decarbonization agency; lack 
TABLE 3 | Systemic Constraints on Malaysia's efforts to decarbonize.

\begin{tabular}{|c|c|}
\hline Constraints & Description \\
\hline Federal-State friction & $\begin{array}{l}\text { Policies enacted by the federal government are not } \\
\text { always implemented by the state governments. This } \\
\text { results from differences in political aims, revenue } \\
\text { streams, capacity, language, and jurisdiction. }\end{array}$ \\
\hline $\begin{array}{l}\text { Limited government } \\
\text { capacity and willingness to } \\
\text { regulate }\end{array}$ & $\begin{array}{l}\text { Malaysia has set ambitious environmental goals but } \\
\text { struggles with enforcement. This is both a result of } \\
\text { capacity limitations, especially at the state level, and } \\
\text { lack of political will. The urban-centered seat and } \\
\text { focus of the federal government further limits its } \\
\text { ability to oversee and enforce mitigation projects } \\
\text { outside of the major urban areas. }\end{array}$ \\
\hline $\begin{array}{l}\text { Absence of dedicated } \\
\text { "decarbonization" agency }\end{array}$ & $\begin{array}{l}\text { Challenges related to collecting data from different } \\
\text { agencies and harmonizing ministry-specific } \\
\text { approaches and policies as well as state-federal } \\
\text { government agendas arise, in part, due to the } \\
\text { absence of a dedicated agency to oversee } \\
\text { Malaysia's transition to a low-carbon development } \\
\text { pathway. }\end{array}$ \\
\hline $\begin{array}{l}\text { Lack of international } \\
\text { funding and support }\end{array}$ & $\begin{array}{l}\text { Promises by the developed world to provide } \\
\text { Malaysia with significant financial and technological } \\
\text { support have not materialized. Malaysia faces } \\
\text { numerous barriers to importing green technologies. } \\
\text { For example, developed countries are unwilling to } \\
\text { share proprietary technologies, thus slowing down } \\
\text { Malaysia's green technology transition. }\end{array}$ \\
\hline Nascent public awareness & $\begin{array}{l}\text { Malaysia's environmental awareness and activism, } \\
\text { particularly concerning climate change, is still in its } \\
\text { infancy. Older generation Malaysians and local and } \\
\text { small and medium enterprises are the } \\
\text { constituencies most disconnected from } \\
\text { environmental concerns. }\end{array}$ \\
\hline $\begin{array}{l}\text { Barriers to renewable } \\
\text { energy adoption }\end{array}$ & $\begin{array}{l}\text { Malaysia's challenge in shifting to renewable energy } \\
\text { are } 2 \text {-fold. First, no one clear renewable energy } \\
\text { alternative exists. Second, the lack of environmental } \\
\text { awareness, financial status of many of its citizens, } \\
\text { and private financing obstacles constrain } \\
\text { investment. }\end{array}$ \\
\hline
\end{tabular}

of international funding and support; nascent public concern about environmental issues (like climate change); and barriers to renewable energy adoption. These are summarized in Table 3.

These constraints, along with Malaysia's efforts to overcome them, can best be understood in the context of the scholarly literature on development pathways.

\section{Path Dependency: Lock-ins and Breakouts}

Path dependency refers to potential barriers to change and how these might be overcome. The path dependence literature points to several processes through which policies become entrenched (i.e., locked-in) as the cost of reversal increases over time (Pierson, 2000; Levin et al., 2012). Seto et al. (2016) identify three main sources of carbon lock-in ${ }^{5}$ : (a) lock-in associated with technologies and infrastructure that indirectly or directly

\footnotetext{
${ }^{5}$ The term "lock-in" is meant to be value-neutral term in that it can either foster positive or negative outcomes, but the authors use "carbon lock-in" to refer to lock-ins that specifically prevent a country from transitioning to low-carbon development (Seto et al., 2016, p. 427).
}

emit $\mathrm{CO}_{2}$ and shape the energy supply; (b) lock-in associated with governance, institutions, and decision-making that affect energy-related production and consumption, thereby shaping energy supply and demand; and (c) lock-in related to behaviors, habits, and norms associated with the demand for energy-related goods and services.

Our findings in Malaysia corroborate these assumptions about carbon lock-in. Infrastructural and technological lock-in creates barriers to renewable energy transition. For example, Malaysia's increased investments in new coal and gas plants make future transitions to RE almost cost prohibitive. Similarly, potential underinvestment in palm biofuel research could undermine the long-term potential of biomass and biogas to compete with other energy sources in Malaysia. Behavioral lock-in maps closely with the slow shift in public awareness. Certain Malaysian social norms form the basis of non-conscious habits that have wider and unintended environmental consequences. Malaysia's culture of consumerism, for example, exemplifies this. Many people focus on the social status accorded to certain purchasing decisions without consideration, or awareness, of the environmental consequences associated with these choices. Institutional lock-in mechanisms partially account for federalstate friction, limited government capacity and willingness to regulate, absence of a dedicated "decarbonization" agency, and lack of international funding and support. In each of these instances, institutional actors seek to stabilize systems that reinforce their own power or help them realize their interests, rather than facilitate radical change.

Despite these constraints, Malaysia has made concerted efforts to transition to a low carbon economy. Individually these efforts appear insignificant, but in concert, they may create the enabling conditions needed to "break out" of carbon lock-in Table 4. These breakout factors include (i) behavioral changes; (ii) engaging a more diverse set of actors; and (iii) enabling institutional shifts by increasing institutional plasticity, encouraging institutional change, and fostering institutional lock-in of an alternative decarbonizing path.

\section{Behavioral Transformation}

One of Malaysia's greatest challenges in "breaking out" of carbon lock-in is related to the difficulty of transforming individual and organizational behavior. The Malaysian government maintains a concerted effort to raise environmental awareness as a long-term strategy to induce behavioral change (Confidential, 2017/2018 2018b, 2018f; Jinggut and Dzulkifli, 2018; Wong, 2018). Nearly $45 \%$ of Malaysia's population is between 18 and 40 years old. One of the government's chief successes has been its focus on youth education and leadership (Confidential, 2018c), as exemplified by two major programs - the TN50 and the development of an Environmental Education curriculum.

In 2017, the Malaysian government led a series of national dialogs among civil servants and youth to outline the 2050 National Transformation Plan, or TN50. TN50 was drafted as a long-term policy planning document outlining the economic, social and environmental targets that Malaysia would need to achieve to make Malaysia a top 20 country in the world by 2050. Whereas Vision 2020 (the precursor to TN50) was drafted 
TABLE 4 | Malaysia's breakout factors from carbon lock-in.

\begin{tabular}{ll}
\hline Breakout factors & Description \\
\hline $\begin{array}{l}\text { Behavioral } \\
\text { transformation }\end{array}$ & $\begin{array}{l}\text { The single-most cited reason for optimism about Malaysia's } \\
\text { ability to transition to a low carbon intensity development } \\
\text { path is related to its concerted effort to transform behavior } \\
\text { by raising environmental awareness. This is reflected in the } \\
\text { development of a new Environmental Education curriculum, } \\
\text { the formal engagement of youth in outlining the National } \\
\text { Transformation Plan for 2050, and the work of NGOs. } \\
\text { Efforts to change behavior in the short term include the use } \\
\text { of feed-in-tariffs and net metering. } \\
\text { A diverse network of actors have worked in concert within } \\
\text { Malaysia's carbon policy ecosystem to shape the current } \\
\text { landscape and future policies and priorities. The federal } \\
\text { government, state governments, international } \\
\text { organizations, NGOs, corporations, and a rising youth } \\
\text { movement all play key roles within and add strength to this } \\
\text { system. } \\
\text { The establishment of a dedicated agency, SEDA, to } \\
\text { oversee renewable energy adoption is the clearest example } \\
\text { of Malaysia fostering institutional lock-in of an alternative } \\
\text { decarbonizing path. }\end{array}$ \\
\hline Institutional shifts
\end{tabular}

and introduced in 1991 through a top-down approach by the government, the TN50 draft process was opened up to civil society and, more importantly, Malaysian youth (Ahmad and Spykerman, 2017). Several respondents pointed to the TN50 draft process as evidence of the rising role of young people in helping to shape national policy in Malaysia (Confidential, 2018b,f).

Starting in October 2016, the Ministry of Youth and Sports (MOYS) was tasked by the Prime Minister to engage youth through dialog, workshops and online channels to capture what younger generations envision for Malaysia's future. Starting in 2018, MOYS and supporting agencies adopted a threephase approach to engaging youth on TN50 that started with mass gatherings, refinement of young people's perspectives and distillation of their suggestions into the TN50 Youth Canvas, which summarizes the perspectives of nearly two million Malaysian youth who engaged in the TN50 draft process (Adnan and Babulal, 2018). Sustainability is featured as one of six major themes highlighted in the TN50 Youth Canvas. Suggestions by the young people involved regarding ways of addressing environment-related challenges include: implementing payment for ecosystem services to allow international bodies, private firms and state governments to pay local communities to manage protected forests sustainably; increasing land-use efficiency in forests and palm plantations to increase their economic viability and sustainability; placing vending kiosks in public spaces where citizens can exchange recyclable goods for points and prizes; and implementing legislation mandating compliance with Environmental Impact Assessment requirements. The future of the TN50 plan is uncertain following the May 2018 election. The new government may push the previous 2020 Vision (Wong, 2018).

A second concerted effort by the government is to develop environmental awareness among Malaysians from a very young age by introducing Environmental Education as a dedicated subject in government-run primary and secondary schools. The
Ministry of Natural Resources and Environment (NRE) and the Ministry of Education started working together in late 2017 to develop the new curriculum, which will focus on clean air, clean water and clean environment (Abas, 2017). Since then, KeTTHA and the National Hydraulic Research Institute have also joined to help with the implementation of the new curriculum in 2019. The hope is that this early introduction to environmental values and civic consciousness will slowly change public awareness (Confidential, 2018a; Ujang, 2018).

Although transforming behavior through improving environmental awareness is critical to ensuring Malaysia's sustainable transition to a low-carbon country, it takes time. In the short term, policies can transform behavior by providing immediate economic incentives, such as incentivizing the adoption of renewable energy technologies through the FiT or NEM. For example, allowing third-party installation of domestic solar panels would increase the attractiveness of existing programs. Private contractors would be incentivized to work with households, installing solar panels in return for a share of the revenue from the electricity generated. Homeowners would benefit by transferring the burden of installation while still achieving lower utility bills. Similarly, full removal of fuel subsidies would further encourage decreased fossil fuel consumption. Malaysia stopped subsidizing automobile gas and diesel in 2014 (primarily due to the high cost of the program), but continues to subsidize liquid petroleum gas, natural gas, and domestic electricity, though the amount of these subsidizes is shrinking. The new government may reverse this trend and increase fuel subsidies (Shirai, 2017; Confidential, 2018f, I14; Gitano-Briggs et al., 2018). As mentioned earlier, the incentives to increase the price of energy to reduce demand are not aligned with KeTTHA's mandate to ensure energy "affordability, reliability and sustainability (in that order)" (Ujang, 2018).

\section{Engagement of a Diverse Set of Actors}

The challenges of lock-in can also be more easily overcome through the involvement of a diversity of actors (Seto et al., 2016). In Malaysia, the federal government, state governments, international organizations, NGOs, corporations, and a rising youth movement all have roles to play if success is going to be ensured.

In certain cases, the success of state-level carbon sector policies and actions can translate into similar federal level action. This process of emulation is analogous to the "laboratories of democracy" concept in the United States, where states function as a proving ground for new policy ideas that subsequently inform federal action. For example, more stringent forest protection in Eastern Malaysia has prompted federal action in Peninsular Malaysia. In addition, the Low Carbon Society Blueprint ${ }^{6}$ developed for the Iskandar development corridor in southern Malaysia helped to build momentum for the countrywide Intended Nationally Determined Contribution [INDC] (2016).

\footnotetext{
${ }^{6}$ The Low Carbon Society Footprint, published in 2013 by the Universiti Teknologi Malaysia (UTM) Low Carbon Asia Research Center, outlines a low-carbon development strategy for the Iskandar region of Malaysia.
} 
Non-governmental organizations, both domestic and international, can also play a role in Malaysia's carbon policy ecosystem by acting as public motivators, government catalyzers, and policy enforcers. Numerous domestic NGOs focus on building public awareness about climate change and environmental challenges in an effort to "put themselves out of business." By raising public awareness and coordinating grassroots action, NGOs have successfully pushed results, such as protecting forest reserves, and earned a seat at the table in creating new policies and programs, such as the Low Carbon City Framework (Hassan, 2016). ${ }^{7}$ NGOs can also mediate among governmental levels and other bodies to help translate legislated policy into implementation. For example, Malaysian non-profits are driving federal forest protection plans by meeting with state governments to encourage state-level implementation. International organizations have also had success in defining decarbonization pathways through policy implementation. The United Nations Development Program (UNDP) ran a project on integrated photovoltaics from 2007 to 2011 that built awareness and showcased the technical feasibility of RE energy. This generated momentum for the 2011 Renewable Energy Act and the establishment of SEDA (Confidential, 2018j, I.21). Similarly, the Japanese Joint Crediting Mechanism ${ }^{8}$ supported the Low Carbon Society Blueprint for Iskandar, which helped motivate subsequent federal climate mitigation action (Japanese Ministry of the Environment, 2014; Gordon, 2016).

Over the past decade, private firms have advanced Malaysian climate mitigation efforts by exercising corporate social responsibility and sector leadership. Corporations have often acted as issue leaders, incorporating sustainable, low carbon practices into their operations in response to consumer pressure and in an effort to reduce costs. International corporations from developed countries have led much of this effort, bringing best practices with them because they have to be responsive to environmentally conscious consumers outside Malaysia. Flagship domestic firms have catalyzed significant change in Malaysia. Large firms have often implemented carbon mitigation programs well ahead of their domestic peers, encouraging responsive action by their competitors.

Finally, Malaysia's global, activist, and increasingly organized youth movement signals stronger national climate action in the future. Young Malaysians already engage in a number of national planning processes where their voice could be amplified in the coming decades.

\section{Institutional Shifts}

One of the most commonly cited obstacles to Malaysia meeting its carbon intensity reduction target relates to the country's institutional landscape. Interviewees cited the need for a central data repository (Amir, 2018; Confidential, 2018a), one agency to oversee coordination of the actions taken by

\footnotetext{
${ }^{7}$ The Low Carbon Cities Framework was introduced by KeTTHA in 2011 in line with the National Green Technology Policy. It serves to guide cities in assessing the carbon emissions and abatement impacts of their development plans.

${ }^{8}$ The government of Japan initiated the Joint Crediting Mechanism to support the diffusion of low carbon technologies, systems and infrastructure in developing countries, with the goal of reducing greenhouse gas emissions.
}

other agencies (Gitano-Briggs, 2017; Confidential, 2018c), increased technical capacity within government agencies (Confidential, 2018e; Ming and Dashun, 2018; Rao, 2018; Wong, 2018), harmonization of state and federal policies (Gitano-Briggs, 2017; Confidential, 2018a,e; Gitano-Briggs et al., 2018; Jinggut and Dzulkifli, 2018; Ujang, 2018), and stronger policy implementation and enforcement by the government (Amir, 2018; Confidential, 2018d; Wong, 2018). Several interviewees pointed to two institutions in particular that ought to be instrumental to Malaysia's transition to a low carbon future - PEMANDU and SEDA.

In 2009, Malaysia introduced the Performance Management and Delivery Unit (PEMANDU) to help design and facilitate the implementation of the 2010 National Transformation Plan (NTP). PEMANDU was established in the Prime Minister's office and became one of the largest and most prominent government delivery units in the world (World Bank Group, 2017). PEMANDU's success was largely due to its role in transforming high-level priorities set by the Prime Minister's office into interventions assigned to specific agencies and ministries; promoting continual stakeholder engagement through the use of "labs" or workshops which allowed participants to work together to design solutions to specific policy challenges; and provision of additional technical support to ministries (World Bank Group, 2017; Confidential, 2018a). PEMANDU's harmonization of the NTP with the country's broader carbon emissions reduction goals was critical to Malaysia's success in remaining on target with its publicly stated ambitions (Confidential, 2018a). Although it was conceived as a temporary institution, PEMANDU's position within the Prime Minister's office gave it the clout and direction it needed to ensure efficient coordination of different ministries given their overlapping efforts to reduce carbon emissions. PEMANDU was dissolved in March 2017 and has since been replaced by the Civil Service Delivery Unit (CSDU) under the Economic Planning Unit in Malaysia (Bernama, 2017). It is not perceived to be as powerful or as focused as PEMANDU (Confidential, 2018d).

The establishment of the Sustainable Energy Development Authority $(\mathrm{SEDA})^{9}$ serves as an illustrative example of the government's attempt to break out of carbon lock-in. It has created a permanent agency dedicated to promoting sustainable energy through implementation of renewable energy-related laws, securing private sector investment in renewable energy (RE), conducting research, and promoting public participation. One of its main functions is to oversee the feed-in tariff (FiT). As of January 2018, SEDA approved a total of 12,190 FiT applications with a total renewable energy capacity of 1,636 megawatts (Borneo Post, 2018). The FiT scheme as a whole has helped the public and private sectors realize that they can make money from renewable energy, slowly changing public perceptions about the benefits of switching to cleaner energy such as solar. Despite the overall success of this mechanism, one criticism has been that the allocation of FiT quotas has not been distributed in a transparent way (Ming and Dashun, 2018). Furthermore, SEDA

${ }^{9}$ SEDA was established under the 2011 Sustainable Energy Development Authority Act. 
no longer holds the regulatory power it needs to be able to award large scale solar farm contracts due to the division of power between KeTTHA and SEDA. ${ }^{10}$ Similarly, proposals to create a National Climate Change Directorate within the Prime Minister's Department to coordinate Malaysia's broader climate change efforts have not advanced due to financial constraints (Wong, 2018).

Malaysia's constraints on decarbonization are not unique relative to other comparable developing countries, many of which have also made bold carbon reduction commitments in recent years. A lack of international support has prevented faster and more extensive technological progress toward decarbonization. This is a limitation that Malaysia shares with many other places around the world. Malaysia's classification as a middle income country further limits international aid, particularly to domestic NGOs, constraining their capacity (Gitano-Briggs et al., 2018).

Malaysia's commitment to behavioral transformation, engaging diverse actors and institutional shifts are key to break carbon lock-in. It provides lessons on the mechanisms and key players that could enable decarbonization in other similar rapidly developing countries. The case of Malaysia has demonstrated the importance of raising awareness and supporting participation across sectors. In particular, the effort to encourage younger generations to learn about and drive progress on climate change must be embraced across all countries in order for collective global action to be effective. The private sector can also advance energy transitions and conservation efforts. These actions can be incentivized through international and national actions. For example, SEDA's work to educate banks about RE to encourage more investment in new technologies. NGOs have driven policy change, demonstrated the social and economic benefits of intact forests, better urban and transportation plans and clean technologies.

Supportive institutions also provide the enabling environment to enact low carbon policies. The steps taken by Malaysia's leadership to demonstrate institutional commitment to decarbonization by establishing an agency like SEDA can serve as an example to other countries that are trying to determine how and in what sequence to implement decarbonization drivers. Malaysia's adoption of an institutional mechanism like PEMANDU, dedicated to integrating the country's development and carbon reduction goals, also demonstrates how a powerful coordinating entity has the potential to make a significant difference in breaking out of carbon lock-in.

\section{CONCLUSION}

Malaysia has been an active supporter of global efforts to address climate change since 2009. The question remains, though, whether or not Malaysia's commitments have been (or can be) translated into actions that make up decarbonization pathways and will eventually reduce carbon emissions significantly. This paper highlights Malaysia's interventions across key sectors,

${ }^{10}$ Media Statement by Dr. Ong Kian Ming, MP for Serdang, on 27th of February, 2016. the programs (and policy tools) that have had the greatest traction, and obstacles to decarbonization that still need to be addressed. We find that (1) barriers to RE (infrastructural and technological lock-in); (2) federal-state friction, limited government capacity, the absence of a centralized agency, the lack of substantial international funding (institutional lock-in); and (3) nascent environmental awareness (behavioral lock-in) are limiting decarbonization.

These barriers are not unique to Malaysia. The country's success in engaging diverse actors, supporting certain institutional shifts, and transforming behavior can serve as illustrative examples for other rapidly developing countries that are facing similar challenges of high population growth, significant levels of poverty and decarbonization. It also points to the significant role of national and international non-state actors and the public as key levers of decarbonization efforts. It is clear that no government will be able to overcome these obstacles alone.

Therefore, we argue that active involvement of nongovernmental actors including private companies, sufficient financial and technical support, and continued public outreach are necessary to break away from path dependencies and recourse to decarbonization pathways. First, other countries should formulate a clear vision and plans for gradually transitioning to renewable energy production, improving energy efficiency, and reducing industry and transport emissions. The combination of policy tools should be tailored to each country and context. A transition to cleaner technologies should be encouraged by international industries and the broader global community. As we see in Malaysia's case, many industry leaders are driven to adopt environmentally sustainable practices so they can remain competitive globally (arguably, more so than because of federal regulation). Second, federal government pledges need to be matched with sufficient financial and technical support to make sure ground level projects can succeed. It helps to have a dedicated agency with political clout, such as PEMANDU in the case of Malaysia, to ensure that the national decarbonization vision is implemented by all relevant agencies and all levels of government. Third, countries should invest in continued outreach to improve environmental awareness among the general public. The greatest sense of optimism expressed about Malaysia's ability to become more environmentally sustainable is attributable to its environmentally savvy youth population. Malaysia has recognized that investing in its youth and engaging large numbers of young people in future planning are critical to changing behavior long-term. The general public needs to be convinced that while there might be higher costs for (renewable) energy in the short term, this will quickly guarantee cost savings and an array of other benefits to the whole society, especially in the long term.

The new government has a rare but short-lived window of opportunity to set Malaysia on a course that strengthens carbon mitigation while promoting a green economic sector. Economic growth and sustainability are not mutually exclusive and can be mutually reinforcing. By investing in advanced palm biofuel, forest ecotourism, and RE installation and production, the new government can meet its pledge to create new jobs and promoting 
economic growth while also driving carbon mitigation. In addition, the new government can reduce barriers, such as tax friction between the federal and state governments, that unnecessarily constrain carbon mitigation and hinder Malaysia's long-term development.

While Malaysia's commitment to an emissions intensity reduction goal is laudable, especially as a developing country, the goal itself is relatively weak, especially in the long-term. The government knew that achieving the 35\% intensity reduction target was virtually assured before making its INDC commitment, and by making the $45 \%$ intensity reduction contingent upon international aid, providing an excuse for not undertaking more aggressive mitigation efforts after reaching the $35 \%$ threshold. The previous government also did not have a longer term vision for moving beyond the $45 \%$ reduction target. One government official commented, "If you're going on a diet, you can't set a higher goal" (Confidential, 2018d, I. 12). If Malaysia does reach its $45 \%$ intensity reduction target, its absolute emissions will almost certainly continue to rise. While increases in total emissions are the norm for developing countries, if left unchecked, this trend paints a worrying picture for the rest of the world. One possible strategy is to first focus on sub-sector $\mathrm{CO}_{2}$ reductions. For example, a specific target of reducing $\mathrm{CO}_{2}$ emission by a certain number of tons in household electricity use in at district level (by providing small incentives for choosing renewable energy sources) can help reframe the emissions reduction goal in absolute terms without directly conflicting with continuous development needs. While these sub-sectors or industry specific ground-level efforts individually may occupy a small portion of the nation's emissions, keeping a transparent account of emission levels in micro-scale will gradually accumulate to useful and accountable footprints.

If global temperature increases are to be kept under $2^{\circ} \mathrm{C}$, Malaysia and other countries will need to set firm carbon reduction goals. The new government should set a date to implement such a goal after it reaches high income status in the next 5 years.

\section{REFERENCES}

Abas, A. (2017). Proposal to Have Environmental Education Subject in Schools Finalised: Environment Ministry. Available online at: https://www.nst.com. $\mathrm{my} /$ news/nation/2017/11/298392/proposal-have-environmental-educationsubject-schools-finalised (accessed April 30, 2018).

Adnan, A. S., and Babulal, V. (2018). TN50 is Malaysia's Dream. New Strait Times. Available online at: https://www.nst.com.my/news/nation/2018/02/ 339984/tn50-malaysias-dream (accessed March 02, 2020).

Ahmad, R., and Spykerman, N. (2017). TN50 - Journey to the Top 20 Begins Today - Nation | The Star Online. Available online at: https:/www.thestar.com.my/ news/nation/2017/01/19/tn50-journey-to-the-top-20-begins-today/ (accessed April 30, 2018).

Amir, A. A. (2018). Interview 20. Institute of Development \& Environment. Bangi, Selangor: The National University of Malaysia.

Au, E. (2016). Mahathir quits Umno, Calling it "Najib's party.". Available online at: https://www.straitstimes.com/asia/se-asia/mahathir-quits-umno-calling-itnajibs-party (accessed April 8, 2018).

Bernama (2017). Pemandu not Privatised, says IDRIS Jala | Free Malaysia Today. Free Malaysia Today. Available online at: http://www.freemalaysiatoday.
Malaysia understandably does not want to constrain its economic growth in its efforts to limit carbon emissions. It has made notable voluntary commitments to the global community to reduce its carbon emissions intensity, but will have to do more. Although it may be challenging to reduce absolute carbon emissions, Malaysia has at least set the intention of decoupling carbon emissions from economic growth. The rest of the global community should recognize, learn from and support this effort.

\section{DATA AVAILABILITY STATEMENT}

The datasets generated for this study are available on request to the corresponding author.

\section{ETHICS STATEMENT}

We obtained approval from the Institutional Review Board at the Massachusetts Institute of Technology.

\section{AUTHOR CONTRIBUTIONS}

LS conceptualized the article and contributed to data analysis, drafting, and revision. JC, SG, GS, and YZ contributed to data collection, research, data analysis, drafting, and revision of the manuscript. JG contributed to research, data analysis, drafting, and revision.

\section{FUNDING}

This research was supported by the MIT-UTM Malaysia Sustainable Cities Program (http://malaysiacities.mit.edu), a collaboration between the Massachusetts Institute of Technology and Universiti Teknologi Malaysia supported by Malaysia's Ministry of Education.

com/category/nation/2017/05/09/pemandu-not-privatised-says-idris-jala/ (accessed April 8, 2018).

Borneo Post (2018). Ministry Embarks on Roadmap to Reduce Greenhouse gas (GHG) Emissions. Available online at: http://www.theborneopost.com/ 2018/04/11/ministry-embarks-on-roadmap-to-reduce-greenhouse-gas-ghgemissions/ (accessed April 30, 2018).

Corbin, J., and Strauss, A. (2008). Basics of Qualitative Research: Techniques and Procedures for Developing Grounded Theory. Thousand Oaks: Sage Publications, Inc.

Confidential (2017/2018). Interview 10. Kuala Lumpur: Malaysian environmental NGO B.

Confidential (2018a). Interview 2. Singapore: International resilience funder.

Confidential (2018b). Interview 3. Kuala Lumpur: Malaysian environmental advocacy NGO A.

Confidential (2018c). Interview 11. Plaza Sentral: Malaysian Banking Institution.

Confidential (2018d). Interview 12. Putrajaya: Malaysian government environmental department.

Confidential (2018e). Interview 14. Kuala Lumpur: Malaysian oil and gas company. Confidential (2018f). Interview 15. Putrajaya: Malaysian government sustainable energy department. 
Confidential (2018g). Interview 16. Petaling Jaya: Sime Darby Plantation.

Confidential (2018h). Interview 17. Kuala Lumpur: Malaysian electricity company.

Confidential (2018i). Interview 21. Kuala Lumpur: International development organization.

Confidential (2018j). Interview 23. Taiping: Mangrove reserve official.

Fankhauser, S., and Jotzo, F. (2018). Economic growth and development with lowcarbon energy: economic growth and development with low-carbon energy. Wiley Interdiscip. Rev. Clim. Change 9:e495. doi: 10.1002/wcc.495

Gitano-Briggs, H. W. (2017). Interview 7. Kuala Lumpur: Universiti Sains Malaysia/ Focused Applied Technologies.

Gitano-Briggs, H. W., Confidential A., and Confidential B. (2018). Interview 6: George Town: Universiti Sains Malaysia

Gitano, H. G., and Leong, H. K. (2016). Malaysia Stocktaking Report on Sustainable Transport and Climate Change. GIZ and ASEAN. Available online at: http://www.mot.gov.my/SiteCollectionDocuments/Darat/MY StockTakingReport_Final.pdf.

Gordon, J. (2016). Low Carbon Development Planning in Iskandar Malaysia: Assessing the Role of Epistemic Communities. Available online at: https://malaysiacities.mit.edu/sites/default/files/documents/jGordon.pdf (accessed May 29, 2018).

Gouldson, A., Colenbrander, S., Sudmant, A., and Papargyropoulou, E. (2014). The Economics of Low Carbon Cities. Palembang: Indonesia.

Green Tech, and Malaysia. (2016). Frequently Asked Questions | Green Technology Financing Scheme (GTFS). Available online at: https://www.gtfs.my/faq (accessed 29, 2018).

Hamid, J. (2008). Malaysia's PM in Danger as Mahathir Quits Party. Reuters. Available online at: https://www.reuters.com/article/usmalaysia-mahathir/malaysia-ex-pm-mahathir-quits-ruling-party-umnoidUSKLR14546620080519 (accessed April 8, 2018).

Harris, J. (2017). Interview 9. Kuala Lumpur: Khazanah.

Hassan, I. M. Z. A. (2016). Low Carbon Cities Framework. Selangor: Green Tech Malaysia.

Higgins, P. (2013). From sustainable development to carbon control: urban transformation in Hong Kong and London. J. Clean. Prod. 50, 56-67. doi: 10.1016/j.jclepro.2012.11.025

Intended Nationally Determined Contribution [INDC]
[NDC (2016). INDC Malaysia Final 27 November 2015 Revised Final UNFCCC. Available online at: http://www4 .unfccc.int/Submissions/INDC/Published\%20Documents/Malaysia/1/INDC\% 20Malaysia\%20Final\%2027\%20November\%202015\%20Revised\%20Final\%20 UNFCCC.pdf (accessed 11, 2017).

Japanese Ministry of the Environment (2014). Feasibility Studies on Joint Mechanism Projects towards Environmentally Sustainable Cities in Asia. Available online at: https:/www.env.go.jp/earth/coop/lowcarbon-asia/english/ project/data/jcm_pamphlet.pdf (accessed May 29, 2018).

Jinggut, T., and Dzulkifli, D. (2018). Interview 18. Kuala Lumpur: Tropical Rainforest Research Center.

KeTTHA (2017a). Green Technology Master Plan Malaysia 2017-2030. Ministry of Energy: Green Technology and Water.

KeTTHA (2017b). National Green Technology Master Plan. Available online at: https://lcs-rnet.org/pdf/locarnet_meetings/2015/4th_annual\%20meeting/ day1/KS1-2.pdf (accessed April 30, 2018).

Khanna, N., Fridley, D., and Hong, L. (2014). China's pilot low-carbon city initiative: a comparative assessment of national goals and local plans. Sustain. Cities Soc. 12, 110-121. doi: 10.1016/j.scs.2014.03.005

Lambright, W. H., Chjangnon, S. A., and Danny Harveym, L. D. (1996). Urban reactions to the global warming issue: agenda setting in Toronto and Chicago. Clim. Change 34, 463-478. doi: 10.1007/BF001 39302

Leong, T. (2018). Malaysia prime minister Mahathir Mohamad's new Cabinet sworn in. The Straits Times. Available online at: https://www.straitstimes.com/asia/seasia/new-malaysian-cabinet-sworn-in (accessed April 8, 2018).

Levin, K., Cashore, B., Bernstein, S., and Auld, G. (2012). Overcoming the tragedy of super wicked problems: constraining our future selves to ameliorate global climate change. Policy Sci. 45, 123-152. doi: 10.1007/s11077-0129151-0

Ming, O. K., and Dashun (2018). Interview 13. Penang: Democratic Action Party/ Penang Institute.

Ministry of Natural Resources and Environment (2015). Malaysia Biennial Update Report To The UNFCCC. Available online at:, https://unfccc.int/files/ national_reports/non-annex_i_parties/biennial_update_reports/application/ pdf/malbur1.pdf (accessed November 28, 2017).

National Biofuel Industry Act (2007). Available online at: https://www.iea.org/ policiesandmeasures/pams/malaysia/name-147425-en.php (accessed April 30, 2018).

Navaratnam, E., and Confidential (2018). Interview 4. Kuala Lumpur: Cenergei and financial firm.

OECD/IEA and IRENA (2017). Perspectives for the Energy Transition: Investment Needs for a Low-Carbon Energy System. Available online at: https://www.irena.org/-/media/Files/IRENA/Agency/Publication/2017/ Mar/Perspectives_for_the_Energy_Transition_2017.pdf?la=en\&hash= 56436956B74DBD22A9C6309ED76E3924A879D0C7 (accessed November 20, 2018).

Pierson, P. (2000). Increasing Returns. Path dependence, and the study of politics. Am. Pol. Sci. Rev. 94, 251-267. doi: 10.2307/2586011

Rao, T. (2018). Interview 8. Kajang: UNITEN.

Razak, N. (2016). Speech at opening of Paloh Hinai Green Technology Park. Paloh Hinai.: Presented at the Green Technology Park Opening.

Roser, M., and Ortiz-Ospina, E. (2017). Global Extreme Poverty. Available online at https://ourworldindata.org/extreme-poverty (accessed April 5, 2018).

Ruxyn, T. (2018). 10 Things Pakatan Harapan Promised To Achieve In 100 Days If They Win GE14. Available online at: http://says.com/my/news/10-janji-100hari-pakatan-harapan-promises-for-their-first-100-days-if-they-win-gel4 (accessed May 11, 2018).

SEDA (2018). SEDA PORTAL. Available online at: http://www.seda.gov.my/ ?omaneg $=00010100000001010101000100001000000000000000000000 \& s=6$ (accessed April 29, 2018).

Seto, K. C., Davis, S. J., Mitchell, R. B., Stokes, E. C., Unruh, G., and Ürge-Vorsatz, D. (2016). Carbon lock-in: types, causes, and policy implications. Ann. Rev. Environ. Resour. 41, 425-452. doi: 10.1146/annurev-environ-110615-085934

Shirai, T. (2017). Tracking Fossil Fuel Subsidies in APEC Economies. International Energy Agency. Available online at https://www.iea.org/publications/insights/ insightpublications/TrackingFossilFuelSubsidiesinAPECEconomies.pdf (accessed May 25, 2018).

Siew, R. (2018). Environment Must be in Top Ten - Letters. Available online at: https:/www.thestar.com.my/opinion/letters/2018/05/18/environment-mustbe-in-top-ten/ (accessed April 8, 2018).

Ujang, Z. (2018). Interview 22. Putrajaya: Ministry of Energy, Green Technology and Water.

UNFCCC (2018a). All NDCs. Available online at: http://www4.unfccc.int/ ndcregistry/Pages/All.aspx (accessed December 13, 2017).

UNFCCC (2018b). REDD+ - Home [REDD+ Web Platform Reducing Emissions from Deforestation and Forest Degradation in Developing Countries]. Available online at: http://redd.unfccc.int/ (accessed June 4, 2018).

UNFCCC (2015). Paris Agreement. Available online at: https://unfccc.int/sites/ default/files/english_paris_agreement.pdf (accessed April 1, 2018).

Wong, I. (2018). Interview 5. Kuala Lumpur: Yayasan Hasanah.

IPCC (2015). Working Group III to the Fifth Assessment Report of the Intergovernmental Panel on Climate Change. Climate Change 2014: Mitigation of Climate Change. Cambridge: Cambridge University Press.

World Bank Group (2017). Driving Performance From the Center: Malaysia's Experience with PEMANDU. Washington, D.C: World Bank.

World Resources Institute and Global Forest Watch (2018). Malaysia | Global Forest Watch. Available online at: https://www.globalforestwatch.org/country/ MYS (accessed April 24, 2018).

Zhu, Z.-S., Liao, H., Cao, H.-S., Wang, L., Wei, Y.-M., and Yan, J. (2014). The differences of carbon intensity reduction rate across 89 countries in recent three decades. Appl. Energy 113, 808-815. doi: 10.1016/j.apenergy.2013.07.062

Conflict of Interest: The authors declare that the research was conducted in the absence of any commercial or financial relationships that could be construed as a potential conflict of interest.

Copyright $\odot 2020$ Susskind, Chun, Goldberg, Gordon, Smith and Zaerpoor. This is an open-access article distributed under the terms of the Creative Commons Attribution License (CC BY). The use, distribution or reproduction in other forums is permitted, provided the original author(s) and the copyright owner(s) are credited and that the original publication in this journal is cited, in accordance with accepted academic practice. No use, distribution or reproduction is permitted which does not comply with these terms. 


\section{APPENDIX A}

TABLE A1 | Overview of Malaysia's sector-specific carbon emissions intensity reduction strategies.

\begin{tabular}{|c|c|c|}
\hline Sector & Industry & Highlights \\
\hline \multirow[t]{13}{*}{ Energy } & Energy Efficiency & Supply side measures: \\
\hline & & Report net energy usage and measures implemented for efficient electrical energy management to the Energy \\
\hline & & Commission \\
\hline & & Promotion of Minimum Energy Performance Standards (MEPS) for domestic appliances \\
\hline & & Demand side measures: \\
\hline & & Raise awareness via Energy Efficiency (SAVE) Program \\
\hline & & National Energy Efficiency Action Plan (NEEAP) \\
\hline & & Government led initiatives on "green buildings" \\
\hline & Renewable Energy & SEDA launched in 2011 \\
\hline & & Power generation sources include biomass, biogas, solar PVs, mini hydros \\
\hline & & Introduction of the FiT \\
\hline & & Development Biogas Facilities at Palm Oil Mills \\
\hline & & Mandatory biofuel blend in diesel fuels for land and sea transport \\
\hline \multirow[t]{5}{*}{ Transport } & Public Transportation & $\begin{array}{l}\text { Land Public Transport Commission established in } 2010 \text { - launched National Land Public Transport Master Plan } \\
\text { (2012-2030) }\end{array}$ \\
\hline & & Expansion of LRT coverage and implementation of MRT \\
\hline & & Introduction of new buses \\
\hline & Infrastructure & Enhance first-last mile connectivity by building parking facilities and terminal hubs, extending pedestrian walkways \\
\hline & Fuel Efficiency & Encourage use of EEVs and CNG \\
\hline \multirow[t]{4}{*}{ Waste } & Waste Management & Implementation of the Reduce, Reuse, Recycle (3R) Program \\
\hline & & Increase waste treatment capacity \\
\hline & & Improve governance of solid waste management \\
\hline & & New technological developments including automation in water collection \\
\hline \multirow[t]{5}{*}{ LULUCF } & Forest management & Establishment of the Natural Resources Conservation Trust Fund (2013) \\
\hline & & Carry out reforestation and enhance measures to reduce illegal logging \\
\hline & & Develop REDD + Strategy to ensure at least $50 \%$ of land remains forested \\
\hline & Water management & $17 \%$ of terrestrial and inland water areas gazette as protected areas by 2020 \\
\hline & Palm oil & Ensure environmental sustainability through MSPO, RSPO, and other sustainability certification schemes \\
\hline Agriculture & Agricultural practices & $\begin{array}{l}\text { Continue promoting certification schemes to guide sustainable agriculture practices: The Malaysian Organic Scheme } \\
\text { and The Malaysia Good Agricultural Practices (MyGAP) }\end{array}$ \\
\hline
\end{tabular}

E.g., Lambright et al. (1996), Higgins (2013), Khanna et al. (2014)).

\section{APPENDIX B}

\section{Common Interview Questionnaire}

1. What is Malaysia doing well in meeting its carbon intensity reduction targets? What can it do better?

2. What are major obstacles or challenges for Malaysia in meeting this target? Can these be overcome, and if so, how? What are your recommendations for success in this endeavor?

3. How do you perceive Malaysia's balance between its environmental sustainability and its economic development goals?

4. In what ways do you interact with and/or cooperate with partners in other sectors in support of Malaysia's decarbonization goals? 